\title{
Notes on the inhabitants of the Himalayas
}

\section{Colonel Tanner}

To cite this article: Colonel Tanner (1891) Notes on the inhabitants of the Himalayas, Scottish Geographical Magazine, 7:11, 581-585, DOI: 10.1080/00369229108732493

To link to this article: http://dx.doi.org/10.1080/00369229108732493

曲 Published online: 27 Feb 2008.

Submit your article to this journal 준

Џll Article views: 7

Q View related articles ¿ 
ance, say, in Chili or in Persia, or anywhere else? To his consul ? He might just as well apply to the nearest telegraph-post. The United States is powerful enough. Yet, during the Argentine Revolution of July 1890, I have seen the British Consulate at Rosario literally besieged by American citizens begging for British safe-conducts. France is powerful enough. Yet, during the last Chilian civil war, I have seen French subjects arrested and otherwise annoyed (until a French warship appeared upon the scene) to an extent which, had they been British subjects, would have brought the guns of H. M. S. Warspite to bear upon the Intendencia at Valparaiso. Germany is powerful enough. Yet she was fain to beg permission (during the same war) of the British Foreign Office to place her subjects resident in Chili under British protection. Let the colonial be well-assured that there is no such passport throughout the entire World as to be able to declare "I am a British subject." I grant that, as matters now stand, it would not add to his dignity abroad to explain that he was a Canadian or a Queenslander. But the amended form, "a subject of the Britannic Confederation," would very soon be understood as synonymous with Noli me tangere. Indeed, from this political point of view, the Colonies have vastly more to gain than even Great Britain herself.

\section{NOTES ON THE INHABITANTS OF THE HIMALAYAS.}

(Read at Meeting of British Association, 1891.)

By Colonel TANNer.

THE inhabitants of the Himalayas may primarily be divided into three or four divisions, distinguished more particularly from each other by their religion, and this without taking any account of their origin, whether Aryan or Mongolian : for the religion of Asiatics forms the basis of their mode of thought and of most of their customs, and in some cases is so mixed up with their laws that their domestic life is almost, if not quite, governed by its tenets. I will, therefore, sketch out from west to east the localities occupied by Mohammedan, Hindu, Buddhist, and indefinite idolatrous mountaineers, whom one is pretty sure to encounter on the Northern Frontier of India.

The Mohammedans occupy the extreme west of the Himalayan regions, and as Sunis form the greater number of the inhabitants of Kashmir proper and of the Indus valley west of Bunji. Largely mixed with Shiahs, they hold Gilgit and Hunza and all Dardistan, by which name I mean the mountain tracts to the west of Gilgit, but nowhere else along the thousand miles between Kashmir and Assam are they to be found, except here and there, as individual or isolated families brought amongst the Hindus or Buddhists by accident.

The Hindus occupy the greater portion of Kumaon, Kangra and all Nipal, as well as the small principalities which form the Simla Hill States, and Kulu also, though in the latter country they can scarcely be called orthodox, and in reality, so far as I am aware, are Sudras, or of 
the lowest class. The history of the many Hindu principalities scattered along the "middle mountains" 1 of the Himalayas is to be found in various Government offices, where many valuable records touching the Himalayan tribes have long been hidden away from public scrutiny. Here I can only say that many of the families of the rajas or chiefs have occupied their present abodes for twenty, and even thirty, generations, notwithstanding the political vicissitudes of the times following the different changes of Mohammedan, Sikh, and Gurkha rule borne by their ancestors. The old feudal castles of these chiefs present many interesting architectural features, except in those instances where hideous so-called European dwellings-often tin-roofed-have been built up over sites but lately occupied by Saracenic and Hindu buildings.

Buddhists hold in the Western and Central Himalayas the exposed elevated tracts to the north of Kashmir, Gurhwal, Kumaon, and Nipal, and occupy the whole of Bhutan.

And lastly I will name Idolaters, of various ill-defined religious or non-religious sects, who inhabit the unknown semi-independent States to the eastward of Bhutan, on both banks of the Sanpo, and the drainage areas of those rivers, unknown to us except in name, which empty themselves into the lower reaches of the Sanpo, between Sadya and Gyala Sindong. These latter, whom I by courtesy call idolaters, should, in fact, be classed amongst those who hold no religious belief whatever, and who, at most, have an indefinite conviction that some unseen malevolent power moves about in the thunder-cloud and tempest, amidst the glaciers, and in dark forbidding places of the earth, whom it might be as well occasionally to propitiate by the offering of the least valuable of their goods.

Of the four divisions into which I arbitrarily dispose of the inhabitants of the Himalayas, the Hindus and Suni Mohammedans are the best known to us, for they have been our constant study for nearly three hundred years, and, as a fruit of such study, we, as the rulers of a great Asiatic possession, have learnt how so to conduct our intercourse with them, generally as rulers, but sometimes as allies and friends, that our just and firm sway is in this age marked by an ever-increasing confidence on both sides. Our toleration of their peculiar and sometimes repugnant prejudices and customs has gained for us the respect, and almost the love, of a great number of the Queen's Asiatic subjects; but with respect to the other divisions I have named, we are not so fortunate; we are much in the dark as to their modes of thought, both from religious and secular points of view, and until we learn more about them we shall continually lay ourselves open to such disastrous rebuffs as we have lately experienced at Manipur.

In the States contiguous to the north of Kashmir, besides the wellknown Suni sect of Mohammedans, we have in addition Shiahs, and a sub-division of the same sect, vaguely known to us as Maulais, followers of Ali, who, by some curious concatenation of circumstances, regard as their spiritual head or Pope a refugee Persian Prince residing in Bombay, 
who holds more authority - not only spiritual, but even temporal一over a vast number of followers in the Upper Oxus States, in Kashmir, in Burmah, and, I believe, even in China, than the constituted rulers of those countries can pretend to exercise. From the far-off Pamir every Maulai feels himself bound to subscribe from his scanty means towards a yearly tribute to his spiritual lord; and across the snowy passes which lie between Central Asia and India this tribute is carried and delivered, regardless of the difficulties which for many stages beset the embassies on their journeys.

In the Encyclopcedia Britannica theShiah sect is treated of in great detail, giving an almost exhaustive account of their history. They were originally simply the partisans of Ali and his descendants. Even in the lifetime of Ali an effort had been made to adore him as an incarnation of the Deity, and in Persia they became divided into several sects, each holding for one or other of the descendants of Ali, and paying him the reverence due to a deity; and we may suppose that the before-mentioned Persian Prince residing in Bombay, and largely given to horse-racing in Western India - in fact, a patron of the Indian turf-is one of the descendants of the original saints so commonly regarded in olden times by the Persians as a person of the greatest sanctity. But the Maulais, as a distinct sect, appear in no published record to have been treated as if they possessed any political weight whatever.

The Persian Prince above alluded to receives adulation, and I believe more substantial recognition, from even the rulers themselves of the Upper Oxus States-those princes who claim descent from Alexander the Great, but who within the past few years have passed under the rapacious rule of the tyrant of Afghanistan. Under one pretext or other the leading and most influential of the Upper Oxus Princes have been made away with by the Ameer, and the rest 'must inevitably meet their fate at the hands of our Afghan ally, whose hands are steeped with the blood of every man of note in his dominions whom he might consider to have been in the least degree inimical to his rule; but such subjects as these, which perhaps verge on Asiatic politics, I must pass over as being other than geographical, and will conclude my remarks on the Shiahs by pointing out the marked difference they exhibit when contrasted with the Sunis and considered as possible subjects of the Queen, and especially in relation to their behaviour to travellers who may go amongst them in search of geographical knowledge.

The Shiahs evince little or no fanatical hatred to us as Kaffirs, and they will more readily allow us our little foibles in the way of eating ham and drinking wine than is permitted by the Sunis. They are, in fact, more get-at-able than the latter, and it seems therefore a pity that Asiatic-British subjects of this sect number so very few families.

The Sunis of Kashmir, a quiet, long-suffering people, have a considerable liking for the English, chiefly, I suppose, because we stand out in such a pleasing contrast against the oppressive and exacting ruling Hindu class. In Gilgit, also, we are well thought of; but in the Indus Valley, round Chilas, amongst a people whom we have never moved, our name carries no authority. So little regard is paid to our prestige that, 
once when Colonel Biddulph had occasion to send some of his baggage over the Indus to Gilgit by the Chilas route, the goods were all sent back by the way they had been brought, with a message that the Chilasis were an independent people, who took no note of the authority of any ruler whatever. Lower down, on the Kaghan border, the tribes of the Indus Valley attacked a survey party under Mr. Scott, who escaped only after making a gallant resistance against great odds. Lower down, again, occur the Miranzais, a Pathan tribe, who have only just during the past year met their deserts from the rifles of our forces. The Indus Valley, with its numerous branch streams which join the main river between Nanga Parbat and the Black Mountain on the Peshawar border, is peopled by a number of interesting clans, of whom we know little beyond what we may learn from one of our trained explorers' reports, published many years back. They are all Sunis and mostly inveterate raiders, and, notwithstanding the repeated punishments inflicted on them year after year, will remain so for ages to come.

On the Indus the Baltis are the only Shiah Mohammedans. They of all mountaineers may be considered the most hardy and enduring under privations that few other human beings could live through. Of small physique, they are excellent mountaineers, and will carry loads over tracks but barely passable for a goat. IIl clad and poorly fed, they endure cheerfully the cold of winter or the great heats of summer. Employed in Simla, and on other hill stations, they give but little trouble to the police, notwithstanding that sometimes many hundreds may be encamped together for months at a time. The Baltis have been classed amongst the Tibetans. I believe many of them are Maulais. Their language may perhaps be a patois of Tibetan, but nothing appears to be known of it. Rondu, a town of Baltistan, is at any rate a Tibetan word; Ron, or Rong, meaning "precipitous," from the great cliffs through which the Indus flows at this place. Iskardu, or Skardu, the fruit-garden of the Indus Valley, is also a part of Baltistan, and the name is Tibetan.

Buddhists now demand for a short time our attention. In the Himalayas they occupy perhaps one-fourth or one-sixth of the habitable area of the mountain chains drained by those rivers eastward of Kashmir, which flow directly into Hindustan; and though the great mass of Tibetan and Bhutanese Buddhists remain persistently aloof from us, yet little by little our frontier officers are becoming acquainted with the ways, and, in one or two instances, with the language of these interesting races. The Buddhists of Sikkim go to our schools, where they readily acquire the knowledge the masters are able to impart; and the friendly manner in which travellers in Sikkim are treated leads one to hope that, so far as these people at least are concerned, we shall soon know all that is interesting regarding them and their ways of life, if we have not already learnt it. It is the same with the Buddhists of Lahaul and Spiti, who have been long under the ken of able observers, who, from time to time, have published interesting and complete notices of the people who inhabit these highly mountainous tracts. But with regard to the semiBuddhist classes who skirt Tibet on the north, and the Hindu population on the south, this cannot be said. Some of these peoples are indeed 
separated from us by the wide belt of the Nipal and Bhutan territories, through which we cannot hope to explore what lies behind, and those tribes with whom we are almost in touch are nevertheless situated so far away from us, that our British officials can spare but a very short period amongst them, and then only at long intervals of time. Mr. Drew, in his standard work, gives much exact information of the tribes who lie along the northern frontier of Kashmir, but the semi-Buddhist tribes now spoken of do not extend so far to the west as to be embraced in his work; and in no other publication that I am aware of are they even mentioned, though, in saying this, I confess that I have not searched through the available records so as to make such a statement authoritatively.

Along the north of Kumaon, a British district of N.-W. Provinces, one may meet one of the clans now spoken of, and round the highly picturesque villages of Budi and Garbiang these interesting and friendly people may be studied at leisure, in a climate which leaves nothing to be desired and amidst some of the grandest features of nature.

Here the people, even in this age, are so unaccustomed to the visits of Europeans, that the inhabitants-men, women, and children -will follow you about, pleased at the evident interest taken in their ways. Without wishing to be rude, and with no idea of intruding on your privacy, they will sit round your tent watching every movement. Every one of them is ready to fetch and carry for you, and, in such broken Hindustani as they can command, ready to reply to any questions you may put. A small looking-glass which I happened to possess was passed by the women from hand to hand, and a group remained for hours arranging their hair and freely passing comments on their own personal appearance, when, for the first time in their lives, examining themselves in my very minute mirror. The headmen are said to have amassed considerable wealth in the transport of borax, which for several generations has been carried through their country to India.

At Budi I witnessed the interesting funeral ceremonies of one of the inhabitants - a two days' affair-including the graceful sword and scarf dance by the men and women, and the hunting and subsequent despatch of a domestic yak, which, after being chased about under volleys of abuse, was speared and eaten. The idea was, that, by heaping indignities on the yak, the departed old woman would presently obtain, in the world to which she had been transferred, that rest and quiet which, as a dweller on earth, had been denied her.

The two villages inhabited by the semi-Buddists are the last towards the east that are accessible to Europeans, for here commences Nipal, which, for five hundred miles, occurs along the Himalayas, till at Sikkim we meet with the friendly people, who may be visited in their villages and in their monasteries, where even casual visitors will be entertained by the monks sitting in conclave with the abbot, if I may so call the head priest. These, in return for the hospitality they entertain you with, will receive any trifling present with thanks, and will pass you on to the next Gonpa or monastery, after having done all in their power to enliven your stay with music or dancing, and the drummers will escort you out of their lands far towards the next stage of your journey.

VOL. VII. 